\title{
Determinants of export intensity in emerging markets: An upper echelon perspective
}

\begin{abstract}
The examination of upper echelon theory is extended to emerging markets and its impact on the export intensity of a firm is analyzed. Based on the study conducted in India, it is investigated if top management team characteristics influences the firm's export intensity. Five characteristics of top management team viz. Educational level, functional heterogeneity, international exposure, age and total tenure in current firm are investigated. Time period of study under consideration ranges from 2008-2011 and fast Moving Consumer Goods, automobile, pharmaceutical and textile industries are analyzed. Evidence is received in support of most of hypotheses. It is found that tenure had curvilinear relationship and international experience had a quasi moderating impact on top management's age and performance relationship. These results differ from those of developed markets
\end{abstract}

Key words: export intensity, top management team characteristics, emerging markets

\subsection{Introduction}

Exports are known to be the quickest mode of entry into international markets (Gao et. al, 2009). This is the reason why management scholars have analyzed the drivers of firm's export strategy in great details (Iyer, 2010; Sou and Stan, 1998; Sterlacchini, 2001). While industrial organizational theory reflects the role of external i.e. macro and industry level factors (Scherer and Ross, 1990); resource based theory highlights role of firm level factors which influence the export intensity (Barney, 1991; Collis, 1991). Thus, at macro level, environmental factors like comparative advantage of countries (Vollrath, 1991), government policies (Zhao, 2002), exchange rate fluctuations (Bernard et. al, 2001) have been investigated to determine export 
intensity of firms; firm's characteristics like firm's age (Moen and Servais, 2002), size (Veerwal and Donkers, 2002), marketing intensity (Leonidou et. al, 2002) and R\&D intensity (Barrios et. al, 2003) have been emphasized as firm's resources which drives its export performance.

However the role of top management team and hence the upper echelon theory has been investigated to a limited extent only in emerging markets like India. Impact of top management team is even more crucial in emerging markets because of presence of institutional voids. (Khanna and Palepu, 2001). Institutional voids in these economies preclude the availability of advisory services, outside expert opinion and surveys to top management, as a result of which composition of top management team w.r.t their knowledge level, risk taking capabilities and attitude becomes even more important w.r.t strategic decisions like generating growth from international markets through exports. Thus, the objective of this paper is to extend previous research conducted in the field of upper echelon to export behavior of firms and to analyze how traits of top management team influences the export intensity of firms in emerging markets like India. We find that impact of top management team on exports is different compared to internationalization studies conducted in developed economies.

The top management team and firm's performance relationship was first explained by (Mason, 1984) who also introduced the upper echelon theory. Since then, this theory has been extensively used to explain variations in international diversification of firms. Top management traits like tenure, age, education etc. were found to be significant determinants of the Internationalization strategy of the firm (Sambharya,1996; Tihanyi et. al, 2000; Herrmann and Dutta, 2005).

However, there are differences in motives of internationalization and exports. For example, internationalization could be driven by resource seeking (Kraemer ,2009) strategic asset seeking 
(Chittoor et. al, 2009), efficiency seeking and learning motives (Neilson, 2002), whereas exports are driven by market seeking motives. Firms from emerging markets, internationalize to acquire strategic assets from developed countries (Bertoni et. al, 2009) Thus, the implications for the information processing by the top management team would be different when the motive is to absorb strategic assets from international market compared to the market expansion motive of a

firm. Hence, examining the role of top management team w.r.t export strategy could yield different results compared to the case when the role is analyzed from the international diversification perspective. Thus, it is vital to investigate impact of top management's team on firms' export intensity in emerging markets like India.

\section{Literature review}

Export intensity is conceptualized as performance of firm in international markets in terms of sales generated in those markets (Shoham, 1998). Amongst macro level factors, apart from industrial organization theory (Meyer, 2006; Peng et. al, 2008) recently institution based theory of organization has been used to explain export behavior of firms. Institutional changes in country foster transparency and enhances market efficiency as a consequence of which business barriers are removed (Child and Tse, 2001). As a agglomerative effect of these factors, firm's export performance increases (Gao et. al, 2010). Another macro environmental theory which has been used to explain export behavior of firm is an organization morphism theory or the institutionalization theory (DiMaggio and Powell, 1983). According to this theory firms would mimic the behavior of their rival firms to assure that they at least meet the industry standards. Thus, if on an average, firms in an industry are securing revenues and growth through exports other firms will also follow them in the industry. (Gao et. al, 2010). 
Firm level determinants of export intensity are based on resource based theory and dynamic capabilities theory (Rodreguez and Rodreguez, 2005; Garcia et. al, 2011). Resource based theory (Barney, 1991) explains how the firm's capabilities could influence its export intensity. Under this paradigm role of innovative capabilities has been extensively studied (Sahaym et. al, 2012; Naughton, 1996). For example, in high-tech industries, R\&D intensity was found to have significant impact on the firm's export intensity (Barber and Alegre, 2007) The traditional assumption regarding export behavior is that a firm needs to be big to operate in international markets. However, some studies have proven this argument wrong, where negative relationship between size and export intensity has been established or no significant relationship has been reported (Calof, 1993). Similarly the relationship between age and export intensity is also well established.

\section{Upper Echelon Theory}

Compared to resource based and dynamic capabilities perspective, upper echelon theory has received comparatively lesser attention in terms of export behavior. Upper echelon theory suggests that many organizational outcomes can be predicted by demographic characteristics and traits of top management team as they are the central tenet of strategy formulation which has implications for the whole organization (Hambrick and Mason, 1984).

Export intensity in the management literature has been investigated from the international diversification point of view and pioneer work in this field w.r.t role of top management team begun with the scholarly work of Sambharya (1996). This was followed by work of Tihanyi et. al, 2000 and Herrmann and Dutta, 2005). These scholars focused on traits like tenure, age, education, international experience and heterogeneity of top management team. For example, Tihanyi et. al, 2000, based on US electronics industry found that with increasing tenure and elite 
education international diversification of firms increased and with an increase in age level of diversification decreased.

But evidences regarding drivers of export intensity from the upper echelon theory especially in emerging markets are non existent. Several studies have been conducted to examine export performance of firms in China, which is one of the (BRIC) emerging markets. (Buck et. al, 2007; Zhao \&Sou, 2002; Sou and Stan, 1998). However, these studies have relied on resource based and capabilities based theory.

Nature of studies covering managerial aspects has focused on their compensation and experience. In this regard, Gourley et. al, 2005 recently found that average pay package of director significantly impacted firm's export behavior. Majocchi et al. (2005) found that changes in business experience influenced export performance of Italian firms for the period of 19972001.

Top management team composition and its dominant logic can have significant impact on the firm's export intensity, depending upon the risk taking propensity of top management teams. (Prahalad and Bettis, 1991). Thus, where macro level factors would influence firms equally in terms of export propensity, it is firm level factors which would influence each firm differently depending upon top management team composition, their capabilities and attitude towards export strategy.

Our objective of this paper is to focus on firm level characteristics specifically top management team characteristics and investigate how the traits of top management team influences export behavior of firms in emerging markets especially India. In Indian context, few studies which have been conducted, had focused on impact of exports on firm's financial performance 
(Contractor et. al, 2007) but not on antecedents of export performance. As we have explained in the introduction section that role of top management team and their information processing capabilities is even more important in emerging markets because of presence of institutional voids, their study is inevitable in an emerging market context. Our results are also slightly different from those earlier arrived in developed markets context. We focus on five traits of top management team viz. Educational level, functional heterogeneity, international exposure, age and total tenure in current organization. In the next section we discuss hypothesis based on upper echelon theory and further conduct empirical investigation of our hypothesis.

\section{Theory and Hypotheses}

\subsection{Educational level}

Higher level of education assures better information processing capabilities and cognitive base which influences top management's team strategic choice (Hambrick and Mason, 1984). Top management teams with higher educational qualifications have a broader perspective of business and are more risk taking. Top management knows their markets well. They are aware of taste and preferences of customers in the home country (Dougall et. al, 2003). However, entering into international market is more risky than providing new product variants within the home country (Collins, 1990). Educational qualification raises competency and overall capabilities of members of top management team, as a result of which they become more inclined to invest in risky strategies. For example, Datta and Rajagopalan, (1998) found that overall openness, willingness to change and investment in innovation increased when top management was highly qualified. 
The dominant logic of top management team would be focused on more risky and more paying off strategies when the top management team is sure of their relational, network and cognitive capabilities (Prahalad and Bettis, 1990). As a result, educated top management team would be able to differentiate their products and services better, hence, their export performance would also increase (Munch and Skaksen, 2008). Hence the hypothesis,

\section{H1 Higher the educational level of top management team, more would be the intensity of exports}

1

\subsection{Functional heterogeneity}

In emerging markets because of presence of institutional voids (Khanna and Palepu, 2001) role of top management team's heterogeneity becomes even more important. For example, unlike in developed countries, good market research firms are not present in emerging markets, which could direct top management about potential target countries for exports or kind of product adaptation required to make it compete in international markets. As a consequence, top management has to rely on expert opinion of internal marketing managers only. Thus, their presence on top management board is inevitable. Similarly, advanced nations have strong and strict contract enforcement mechanisms, so the propensity of opportunistic behavior is automatically reduced. However, in emerging markets, because of soft infrastructure, this is not possible, hence a appointment of top management member with law background is unavoidable, as he or she would be able to give expert opinion on contract enforcement mechanisms. 
According to the theory of bounded rationality, managers have limited cognitive ability to process information thus, they tend to take satisficing decision rather than best optimal decision. A homogenous team of upper echelon is more likely to think and process the information in the same manner. This presents advantage as well as a disadvantage to the firm. Homogeneity of the team would imply less of conflicts and more conformity within top management team members. For example, if the top management team consists of a majority of engineers and very few human resource professionals, then while processing information and making decisions, entire orientation would be bent towards the technical aspect of the business and the manpower problem associated with the strategic decision of exports may be missed upon. Thus, technically bent top management team would be competent enough to deal with technological problems and will look for export opportunities from a technical point of view and will overlook problems associated with human resource management while implementing exports strategy. Similarly, if the top management team lacks marketing and business development professionals then technically bent top team can become more aligned towards investment in research and development for new product development which suits home country thus, overlooking opportunities existing in other markets where same technology could be utilized.

These problems can be overcome if the top management team is more heterogenous in nature. This implies that heterogenous team will have divergent viewpoints, different outputs of information processed, more conflicts and complex set of skill sets. This heterogeneity would be more useful especially if environment is more complex and dynamic. Heterogenous team has been found to moderate the relationship of innovation and advice seeking role (Alexiev et. al, 2010). Even investors prefer heterogenous teams compared to homogenous teams. In a study conducted by (Zimmerman 2008), it was found that more capital was raised by firms during IPO, 
whose top management team was more heterogenous. Though conflicts are more in a heterogenous top management team but at the same time heterogenous team is also found to facilitate strategic changes in the organization which then improves performance of the firm (Naranjo-Gill, et al, 2007).

Overall, top management team which is heterogeneous in nature would look at the problem and challenges associated with exports from different angles which will raise their capacity and potential for exports.

Thus, based on these arguments it is postulated that

\section{H2 Heterogenous teams are positively associated with the export intensity of the firm}

\subsection{International exposure of top management team}

Successful exporting requires that top management has either knowledge about international market or orientation to learn about international operations. (Johanson and Vahlne, 1977). Top management which has international exposure either in terms of work experience or educational qualifications are found to have a more international orientation (Gunz and Jaland, 1996). Different cultures, different living habits, different ways of doing business influences their attitude and perceptions, which is reflected in the way they formulate strategies. Awareness of different culture prepares them well for doing business with international partners. Once the top management internalize processes associated with different countries, it makes them well equipped to operate in international markets. For example, they are able to adapt pricing of their 
products in a more apt way which then enhances their export performance (Sousa and Bradley, 2008). In other words international exposure enhances top management team's capabilities to deal with uncertainties associated with international markets. (Sambharya, 1996).

Moreover, because of international exposure top management team also develops some external ties and relational capital(Gulati, 1995) which makes access to information and its processing much easier compared to the case when top management does not have any international exposure. For example, Lee and Park (2008) found that top management with international exposure had a positive and significant association with the international alliance formation. Similarly, Eberhard and Craig (2012) found that inter-organizational networks positively influenced international market venturing by small and medium size enterprise. Thus, leveraging on relational capital top management team with international experience can easily build export channels required to capture opportunities existing in host country markets. Thus, we hypothesize

\section{H3 International exposure of top management team is positively associated with exports}

\section{intensity}

\subsection{Age}

Past research suggests that the age of top management team influences the strategic decision taken by firms (Weirsema and Bantel, 1992). Younger top management team is more enthusiastic and has more propensity and ability to take risk, as a result of which they tend to take riskier strategic decisions. As top management team ages, they become more risk averse and more conservative towards risky strategies. Stability rather than growth becomes their goal and objective. Further, personal agendas of financial and career stability becomes more important for 
older executives compared to younger executives. Leveraging on exports is a risky strategy, compared to capacity expansion within the same country (Li and Quan, 2008). This is because the economic risk of currency fluctuation and exchange risk increases which may result in lower cash flows if the home country's currency is devalued. Secondly to understand international market, broader marketing knowledge and more information processing are required, in which older upper echelon may not be interested. Thus, riskiness coupled with learning effects would discourage top management team to opt for exporting of products and services. But the past international experience of top management team either in terms of prior employment or education, will lessen their risk perception of operating in international markets. Thus, though with age, rigidity of operating in the home country increases, prior experience in the international market will make them more receptive for conducting business in foreign countries.

Hence the hypothesis:

H4 (a) Average age of top management team will have a negative impact on export intensity

H4 (b) International experience will have a moderating impact on the relationship between export intensity and average age of top management team

\subsection{Organizational Tenure:}

Tenure of top management team provides both advantages and disadvantages to export strategy of the firm. As tenure of top management team increases, their predictive ability of competitive environment increases (Dixit and Nalebuff, 1991). Export strategy poses several challenges to top management team. First of all they have to compete with local suppliers in host country, then 
they have to fulfill regulatory formalities, search for the appropriate export market, where demand of the product exists. As a top management team would age in the organization they would climb the learning curve and would be able to leverage better on export strategy by virtue of past experience they had with exporting In other words, top management team would be able to tackle challenges of exports in better manner as they grow over time. Also cohesion amongst top management members would increase with time, as a result of which disputes over market location and supplier selection would be sorted faster (Bantel and Jackson, 1989). Hence the export strategy would be implemented even faster resulting in more exports intensity. But after a certain point of time, top management team would develop a myopic view of the business environment and would not read changes in the macro environment. Thus, if other economies are also opening and competition in international markets is increasing, top management team with longer duration will remain unaffected as they have would have developed a narrow and rigid view of the business environment (Smith, 2005; Pan and Jaju, 2001). Thus, other competitors would start occupying competitive turf and performance of firm with longer tenure of top management team would decline, hence their export intensity would decline.

Other studies have also shown that as tenure of an executive in the organization increases, he starts conforming to the norms of the organization and his cognitive structure becomes more rigid (Umokoro, 2009). Miller (1991) found that as tenure of CEOs in the organization increased, their ability to change the strategies and fit them with the changing environment decreased. Many organizations failed to successfully turnaround their organizations because CEOs believed in success formulas and were not willing to change their strategies to counterattack competitive challenges. Finkelstein and Hambrick (1990) found that as the tenure of top management team in 
the organization increased, their tendency to adhere to strategies pertaining as per industry norms increased.

Since top management team's tenure provides advantages in terms of competitive reasoning, learning abilities and cohesiveness with an increase in tenure; as well as disadvantages in terms of myopic and rigid view of the environment, we hypothesize

\section{H5: Top management team's tenure follows the curvilinear relationship with exports intensity.}

\subsection{Data and Methodology}

We selected some of the fastest growing industries in India to conduct our study. These industries are automobile, pharmaceuticals, FMCG and Textiles. We collected data for three years i.e. from 2008-2011. Our total sample size was 350 firms. Though these firms are a miniscule representation of the total population of above mentioned four industries but other firms could not be taken mainly because of two reasons. Firstly, data on top management team was not available for many firms especially for small sized firms and secondly there was missing financial data on many other firms thus, calculating export intensity was difficult.

Following approach of Weiresema and Bantel (1992), top management team was defined as members consisting of chief executive officer, chief operating officer, chairman, president, executive vice president etc. Thus, two top most levels of hierarchy were used as measure of top management team. Data on demographic details were collected from the company's website and other sources like google news etc. Company's website generally provided biographic details of its top management team. Thus, age of the member, its tenure in the organization, education level and specialization i.e. highest degree earned was figured out from either websites of the 
companies or their annual reports. For educational specialization, logarithm of total tenure of formal education of top management team was considered as an operationalizable variable (Fenkelstein and Hambrick, 1990). For calculating tenure in organization natural logarithm of number of years were taken. To quantify heterogeneity in specialization, blau's index (1977) was used with the formula $1-\sum \mathrm{p}_{\mathrm{i}}{ }^{2}$, where $\mathrm{p}_{\mathrm{i}}$ is the proportion of group members in the ith category. International exposure of top management team was calculated as the total number of years each top management member has spent abroad and then average international exposure was calculated using the formula: summation of the number of years of exposure of each top management team divided by the total number of top management members (Lee and Park, 2008). Apart from these independent variables, various control variables were also used. These were firm's age and size (Tallman \& Li, 1996) and prior organizational performance (Geringer et al., 1989). Data on firm's age and firm's size was obtained from prowess. Firm's age was calculated from year of incorporation of firm and size was measured in terms of total assets of the firm and again natural logarithm was taken. Prior research also indicates that prior performance of firm in home market could influence its decision of going across borders (Dunning, 1993). Thus firm's past performance was measured as its return on sales. Apart from this, industry structure would also influence firm's propensity to diversify. For example, the nature of demand conditions, government policy and regulations would also effect the firm's decision to go international. Thus, industry as control variable was also included by way of dummy variables. Amburge and Miner (1992).

\section{Analysis}

We have taken five independent variables viz. Educational level, functional heterogeneity, international exposure, average tenure in the company and average age of top management team. 
Along with these variables we have incorporated three control variables also controlling for industry effect, age of the firm and size of the firm. Dependent variable under consideration is export intensity. We use Tobit model with a lower limit specified as zero. Representation of the model is as follows

\subsection{Results}

Table 1 displays mean, standard deviation and Pearson correlations

Table 1 to be inserted here

Table 2 to be inserted here

Table 1 gives the description of mean, standard deviation and correlation coefficients of variables under study. Table 2 presents results of panel Tobit regression. Since dependent variable presents a ratio, its value ranges between 0 to 1 . Hence it is a censored variable, which implies usage of Tobit regression. Model 1 of table 2 shows the results of Tobit regression with 
only control variables. We found that industry effects and firm's age had significant impact on its export performance. Model 2, 3 and 4 presents the result of our first to fifth hypothesis. We see that beta coefficient of tenure of education $(\beta=0.147, \mathrm{p}<0.000)$, functional heterogeneity $(\beta=$ 0.157, $\mathrm{p}<0.005)$, international exposure $(\beta=0.122, \mathrm{p}<0.000)$, and age of TMT $(\beta=-0.01$, $\mathrm{p}<0.05)$ are significant and positive, except for age where the beta coefficient is negative. Thus, we receive evidence in support of our hypothesis concerning level of education, functional heterogeneity, international exposure and age of top management team. These results are consistent with past studies conducted in developed economies (Tihany et. al, 2000; Hermann and Dutta, 2005). In case of functional heterogeneity, Hermann and Dutta, 2005 found that impact was not statistically significant, whereas this is not the case in emerging economies. Functional heterogeneity is not only significant but its beta coefficient has highest value compared to coefficient of other traits like duration of education, international exposure and age.

We further find from model 2 and model 3 of table 2 that the average tenure of top management team follows a curvilinear relationship with export intensity i.e. it first increases with increase in tenure $(\beta=0.142, p<0.000)$ and then decreases i.e beta coefficient of tenure ${ }^{2}(\beta=-0.072$, p $<0.05)$. Study of Tihanyi et. al (2000) reflected that tenure has a positive impact on the export intensity whereas according to Hermann and Dutta, 2005, tenure has negative impact on export performance. Our study indicates that tenure will follow curvilinear relationship with export performance for the reasons we have explained in hypothesis section. For hypothesis regarding moderating impact of international exposure we find that, international experience of top management team acts as a quasi moderator i.e. it has both direct and moderating impact on the firm's export intensity. We find that age of top management team has negative impact on firm's export performance, but an interaction term of age and international experience is significant and 
positive $(\beta=0.037, \mathrm{p}<0.05)$, thus reflecting that when a top management team has prior international experience, then with the increase in age their export performance increases. Thus, the impact of age on firm's export behavior is positively and significantly moderated by international exposure of top management team. Again this relationship is peculiar of emerging markets.

\section{Managerial Relevance}

In the fast moving liberalization, privatization and globalization, it is important for firms to exploit opportunities and tap not only national markets, but also international markets. Exports in such a case provide a quick platform for entering into international markets. However, because of exchange and political risk involved in operating from different countries, not all managers are willing to take such financial risk. In this context, our study provides meaningful findings w.r.t what type of top management team would opt for export strategy especially when firms cannot afford to maintain the status quo. It should be assured that the top management team consists of highly educated managers and they belong to different functional domains. Further, if a firm wants to leverage on exports then older employees should be accommodated in the top management team, provided they have international experience.

\subsection{Conclusion and Discussion}

Our study extends the application of upper echelon theory and its importance in emerging markets and especially export performance of firms in emerging markets. We find that top management education, functional heterogeneity and international experience positively impacts the export intensity of firms. We further find that tenure of top management team has a 
curvilinear impact on export behavior of firms and international experience positively moderate impact of age of top management team on firm's export intensity.

Our study makes the following contributions to the field of drivers of the export performance of firms: Firstly, our study extends the application of top management team's trait theory in emerging markets, where due to presence of institutional voids, demographic profile of top management team becomes even more important. Secondly, the upper echleon theory has been discussed from the international diversification perspective, which can be driven by strategic assets and resources seeking motives also especially in case of emerging markets (Chittor et al, 2009). By focusing on export, we make a clear case of information processing and decision making process of top management team, where exports are driven only market seeking and efficiency seeking motives.

Thirdly, export intensity in emerging markets has been studied from resource based theory perspective and that too most of the studies are conducted in only one of the emerging markets i.e. China (Liu and Yi, 2011). By focusing on India which is yet another fast growing emerging market, we are able to extend and verify the application of the upper echelon theory in other emerging markets as well. Fourthly, our analysis provides an additional and more corroborative evidence that the top management team does impacts organizational outcomes through their strategic decisions (Cyert and March, 1963). Finally, our results indicate that impact of top management team's traits on the firm's performance is not as only linear as reflected in studies conducted in developed economies. Traits have both curvilinear and moderating impact on export behavior. 


\subsection{Limitations and future research}

We have taken data from only three manufacturing industries. This is because of the constraints of the available data. We have applied upper echelon theory to the export behavior of firms in emerging markets. However, role of upper echelon should also be analyzed from the international diversification perspective. As the motives of international diversification of firms from emerging markets are more learning and strategic assets seeking oriented, impact of the traits to explain the relationship may change. But this can be observed if other measures of international diversification like strength of foreign employees or ratio of foreign assets to total assets are used. Role of the demographic profile of top management team can also be used to analyze entry mode decisions of top management team.

\section{References}

Alexiev, A. S., Jansen, J. J. P., van den Bosch, F. A. J., \& Volberda, H. W. 2010. Top Management Team Advice Seeking and Exploratory Innovation: The Moderating Role of TMT Heterogeneity. Journal of Management Studies, 47, 1343-1364

Amburgey, T. L. and Miner, A. S. (1992). 'Strategic momentum: The effects of repetitive, positional, and contextual momentum on merger activity. Strategic Management Journal, $13,335-348$ 
Barney, J. (1991). Firm resources and sustained competitive advantage. Journal of Management, 17, 99-120.

Barrios, S., Görg, H., \& Strobl, E. (2003). Explaining Firms' Export Behaviour: R\&D, Spillovers and the Destination Market*. Oxford Bulletin of Economics and Statistics, 65(4), 475-496.

Bernard, A. B. Wagner, J.(2001) Export Entry and Exit by German Firms, Review of World Economics

Blau, P. 1977. Inequality and heterogeneity. New York: Free Press

Boeker, Warren (1997) Executive migration and strategic change: The effect of top management movement on product entry Administrative Science Quarterly

Calof, Jonathan (1994) Relationship between firm size and export intensity Journal of International Business Studies25(2)pp:357-367

Collis, D.J. (1991) A Resource-Based Analysis of Global Competition: The case of the Bearings Industries. Strategic Management Journal, Volume 12, Summer: 49-68.

Contractor, F; Kumar, V and Kundu, S.K (2007) Nature of relationship between international expansion and performance: The case of emerging markets. Journal of World Business, 42, 401417 
Datta DK, Rajagopalan N. 1998. Industry structure and CEO characteristics: An empirical study of succession events. Strategic Management Journal, 19, 833-852.

Eberhard, M. and Craig, J. (2012) The evolving role of organizational and personal networks in international market venturing. Journal of World Business, forthcoming

Finkelstein, S. and D. C. Hambrick (1990). 'Top management- team tenure and organizational outcomes: The moderating role of managerial discretion', Administrative Science Quarterly, 35, 484-503

Garcia, Francisco; Lucía Avella and Esteban Fernández (2011) Learning form exporting: Moderating role of technological capabilities International Business Review, 21, 102-119

Gourlay, A., Seaton, J., \& Suppakitjarak, J. (2005). The Determinants of Export Behavior in UK Service Firms. Service Industries Journal, 25, 879-889.

Hambrick, D., Mason, P. (1984). Upper echelons: the organization as a reflection of its top managers. Academy of Management Review, 9, 193-206.

Herrmann, P., \& Datta, D. 2005. Relationships between top management team characteristics and international diversification: An empirical investigation. British Journal of Management, 16, $69-78$ 
Johanson, Jan and Jan-Erik Vahlne (1977) The Internationalization Process of the Firm-A Model of Knowledge Development and Increasing Foreign Market Commitments Journal of International Business Studies 8, 23-32

Lee, H. U., Park, J. H. (2008). The influence of top management team international exposure on International alliance formation. Journal of Management Studies 45, 961-981.

Liu, Yuan, Li and Xue, J. (2011) Ownership, Strategic Orientation and internationalization in emerging markets. Journal of World Business, 46, 381-393

Majocchia, A., E. Bacchiocchib and U . Mayrhoferc. (2005). Firm Size, Business Experience and Export Intensity in SMEs: A Longitudinal Approach to Complex Relationships, International Business Review. 14,719-738.

Moen, Ø., \& Servais, P. (2002). Born global or gradual global? Examining the export behavior of small and medium-sized enterprises. Journal of International Marketing, 49-72.

Naranjo-Gil, D., and F. Hartmann. 2007. Management accounting systems, top management team heterogeneity, and strategic change. Accounting Organizations and Society 32, 735 756.

Naughton, B. (1996). China's emergence and prospects as a trading nation. Brookings papers on economic activity, 2, 273-344. Washington, DC: Brookings Institution. 
Rodriguez, J. L. and Rodriguez R. M. G.( 2005), Technology and Export Behavior: A Resource based View Approach, International Business Review, 14, 539-557.

Root, Franklin (1994) Entry strategies for international market, $2^{\text {nd }}$ Ed., Lexington Books

Sambharya, Rakesh (1996) Foreign experience of top management team and international diversification strategies of US multinational corporations, Strategic Management Journal, 17 $739-746$

Sousa, C. and Bradley, F (2006) Antecedents of international pricing adaptation and export performance. Journal of World Business, 43, 307-320

Tallman, S. Li, J. (1996) Effects of International Diversity and Product Diversity on the Performance of Multinational Firms, Academy of Management Journal 39, 179-196

Tihanyi, L., Ellstrand, A. E., Daily, C. M., \& Dalton, D. R. (2000). Composition of the top management team and firm international diversification. Journal of Management, 26: 11571177.

Thomas Vollrath, (1991). A theoretical evaluation of alternative trade intensity measures of revealed comparative advantage,"Review of World Economics, 127 265-280, 
Pla-Barber, J. P., and Alegre, J., (2007), analyzing the link between export intensity, Innovation and firm size in a science-based industry, International Business Review, 16 ,275293

Scherer, Frederic and David Ross, [1970] 1990. Industrial Market Structure and Economic Performance, 3rd ed. Houghton-Mifflin

Shoham, A. (1998). Export performance: a conceptualization and empirical assessment. Journal of International Marketing, 59-81.

Sahaym, Arvin ; Len J. Treviño, and H. Kevin (2012) The influence of managerial discretion, innovation and uncertainty on export intensity: A real options, International Business Review

Verwaal, E., \& Donkers, B. (2002). Firm size and export intensity: Solving an empirical puzzle. Journal of International Business Studies, 33(3), 603-613.

Wiersema, Margarethe, and Karen Bantel. (1992). “Top Management Team Demography and Corporate Strategic Change.” Academy of Management Journal 35: 91-121.

Zimmerman, M. A. (2008). The influence of top management team heterogeneity on the capital raised through an initial public offering. Entrepreneurship Theory \& Practice, 32, 391-414 
Table 1

\begin{tabular}{|c|c|c|c|c|c|c|c|c|c|}
\hline & & 1 & 2 & 3 & 4 & 5 & 6 & 7 & 8 \\
\hline & & & & & & & & & \\
\hline 1 & $\begin{array}{l}\text { Export } \\
\text { Intensity }\end{array}$ & 1 & & & & & & & \\
\hline 2 & $\begin{array}{l}\text { Education } \\
\text { level }\end{array}$ & $0.7042 * * *$ & 1 & & & & & & \\
\hline 3 & $\begin{array}{l}\text { Functional } \\
\text { heterogeneity }\end{array}$ & $0.644 * * *$ & $0.446^{* * *}$ & 1 & & & & & \\
\hline 4 & $\begin{array}{l}\text { inter. } \\
\text { exposure }\end{array}$ & $0.726 * * *$ & $0.125^{* * *}$ & $0.036^{* *}$ & 1 & & & & \\
\hline 5 & Tenure & $0.736 * * *$ & $0.597^{* * *}$ & $0.161 * * *$ & $0.242 * * *$ & 1 & & & \\
\hline 6 & Age TMT & 0.0001 & 0.1668 & $0.245^{* *}$ & -0.0088 & 0.1636 & 1 & & \\
\hline 7 & Lnsize & 0.0909 & 0.1495 & 0.238 & 0.1278 & 0.0861 & 0.0791 & 1 & \\
\hline 8 & Lncomage & -0.0516 & -0.0181 & 0.0618 & -0.2123 & -0.0568 & 0.0345 & -0.157 & 1 \\
\hline & Mean & 0.268679 & 0.336165 & 0.36805 & 2.163126 & 1.182981 & 3.673744 & 6.654024 & 3.398879 \\
\hline & S.D & 0.032544 & 0.018519 & 0.019895 & 0.115093 & 0.078484 & 0.075248 & 0.152718 & 0.065171 \\
\hline
\end{tabular}


Table 2 Tobit Regression Results

\begin{tabular}{|c|c|c|c|c|c|c|c|c|}
\hline & Model 1 & & Model 2 & & Model 3 & & Model 4 & \\
\hline Export intensity & Coef. & Std. Err & Coef. & $\begin{array}{l}\text { Std. } \\
\text { Err. }\end{array}$ & Coeff & Std. err & Coeff & Std. err \\
\hline Pharmaceuticals & $0.670 * * *$ & 0.0791 & $0.189 * * *$ & 0.053 & $0.139^{* *}$ & 0.049 & $0.139^{* *}$ & 0.049 \\
\hline Automobile & $0.048^{* *}$ & 0.079 & $0.194 * *$ & 0.042 & $0.171^{* *}$ & 0.04 & $0.170^{* *}$ & 0.04 \\
\hline FMCG & 0.031 & 0.087 & 0.171 & 0.046 & $0.164 * *$ & 0.043 & $0.163^{* *}$ & 0.043 \\
\hline Educational level & & & $0.147^{* * *}$ & 0.074 & $0.101 * * *$ & 0.016 & $0.101 * * *$ & 0.017 \\
\hline $\begin{array}{l}\text { Functional } \\
\text { heterogeneity }\end{array}$ & & & $0.157 * *$ & 0.077 & $0.151^{* *}$ & 0.07 & $0.150^{* *}$ & 0.071 \\
\hline International exposure & & & $0.122 * * *$ & 0.017 & $0.115 * * *$ & 0.066 & $0.102^{* *}$ & 0.008 \\
\hline Lntenure & & & $0.142^{* *}$ & 0.019 & $0.143^{* *}$ & 0.017 & $0.143^{* *}$ & 0.017 \\
\hline Lntenure2 & & & & & $-0.172 * *$ & 0.0158 & $-0.172 * *$ & 0.015 \\
\hline Lnage & & & -0.01 & 0.017 & -0.029 & 0.002 & -0.013 & 0.01 \\
\hline Lnage*Intl exposure & & & & & & & $0.137 * *$ & 0.043 \\
\hline Lnsize & $0.112 * *$ & 0.018 & 0.007 & 0.009 & $0.057 *$ & 0.008 & 0.056 & 0.008 \\
\hline Lncompany age & $0.113^{*}$ & 0.019 & $0.121 *$ & 0.011 & $0.022 *$ & 0.01 & 0.011 & 0.01 \\
\hline
\end{tabular}




\begin{tabular}{|l|l|l|l|l|l|l|l|l|}
\hline Industry growth & $0.115^{*}$ & 0.02 & $0.115^{*}$ & 0.03 & 0.010 & 0.01 & 0.021 & 0.013 \\
\hline Intercept & $0.127^{* *}$ & 0.059 & $0.405^{* *}$ & 0.104 & $0.402^{* *}$ & 0.081 & $0.401^{*}$ & 0.083 \\
\hline
\end{tabular}

$*$ significant at $10 \%$ level, $* *$ significant at $5 \%, * * *$ significant at $1 \%$ level 